\title{
INSTRUMENTATION USED FOR HYDRAULIC TESTING OF POTENTIAL WATER-BEARING FORMATIONS AT THE WASTE ISOLATION PILOT PLANT SITE IN SOUTHEASTERN NEW MEXICO
}

$$
\text { Ry Z. A. Rasler }
$$

U.S. GEOLOGICAL SURVEY

Open-File Report 83-144

Albuquerque, New Mexico 1983 


\author{
UNITED STATES DEPARTMENT OF THE INTERIOR \\ JAMES G. WATT, Secretary \\ GEOLOGICAL SURVEY \\ Dallas L. Peck, Director
}

For additional information write to:

District Chief

U.S. Geological Survey

Water Resources Division

505 Marquette, N.W., Room 720

Albuquerque, New Mexico 87102
For sale by:

Open-File Services Section

Branch of Distribution

U.S. Geological Survey, MS 306

Box 25425, Denver Federal Center

Denver, Colorado 80225

(303) 234-5888 


\section{CONTENTS}

Abstract $\ldots \ldots \ldots \ldots \ldots \ldots \ldots \ldots \ldots \ldots \ldots \ldots \ldots \ldots \ldots \ldots \ldots \ldots \ldots \ldots \ldots \ldots \ldots \ldots \ldots \ldots \ldots . . \ldots{ }^{\text {Page }}$

Introduction $\ldots \ldots \ldots \ldots \ldots \ldots \ldots \ldots \ldots \ldots \ldots \ldots \ldots \ldots \ldots \ldots \ldots \ldots \ldots \ldots \ldots \ldots \ldots$

Acknowledgments.$\ldots \ldots \ldots \ldots \ldots \ldots \ldots \ldots \ldots \ldots \ldots \ldots \ldots \ldots \ldots \ldots \ldots \ldots \ldots \ldots$

Equipment requirements $\ldots \ldots \ldots \ldots \ldots \ldots \ldots \ldots \ldots \ldots \ldots \ldots \ldots \ldots \ldots \ldots \ldots \ldots \ldots \ldots$

Downhole components $\ldots \ldots \ldots \ldots \ldots \ldots \ldots \ldots \ldots \ldots \ldots \ldots \ldots \ldots \ldots \ldots \ldots$

Packer $\ldots \ldots \ldots \ldots \ldots \ldots \ldots \ldots \ldots \ldots \ldots \ldots \ldots \ldots \ldots \ldots \ldots \ldots \ldots \ldots \ldots \ldots \ldots, \ldots \ldots \ldots$

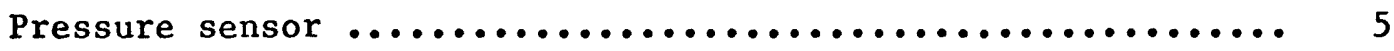

Signal cable .................................. 5

Transducer housing $\ldots \ldots \ldots \ldots \ldots \ldots \ldots \ldots \ldots \ldots \ldots \ldots \ldots \ldots$. 7

Surface components $\ldots \ldots \ldots \ldots \ldots \ldots \ldots \ldots \ldots \ldots \ldots \ldots \ldots \ldots \ldots \ldots \ldots$

Amplifier $\ldots \ldots \ldots \ldots \ldots \ldots \ldots \ldots \ldots \ldots \ldots \ldots \ldots \ldots \ldots \ldots \ldots \ldots \ldots \ldots \ldots, \ldots \ldots \ldots$

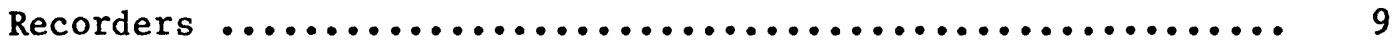

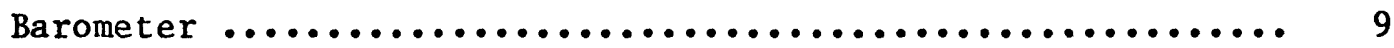

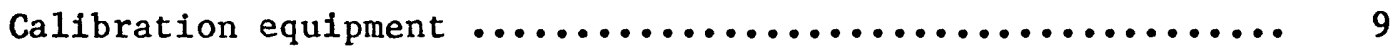

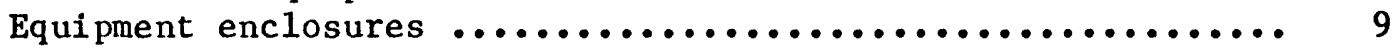

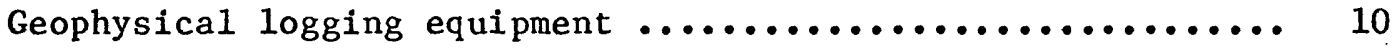

System accuracy $\ldots \ldots \ldots \ldots \ldots \ldots \ldots \ldots \ldots \ldots \ldots \ldots \ldots \ldots \ldots \ldots \ldots \ldots \ldots \ldots \ldots$

Methods of testing $\ldots \ldots \ldots \ldots \ldots \ldots \ldots \ldots \ldots \ldots \ldots \ldots \ldots \ldots \ldots \ldots \ldots \ldots \ldots$

Open-casing tests $\ldots \ldots \ldots \ldots \ldots \ldots \ldots \ldots \ldots \ldots \ldots \ldots \ldots \ldots \ldots \ldots \ldots \ldots \ldots \ldots \ldots \ldots \ldots$

Recovery from bailing ............................... 15

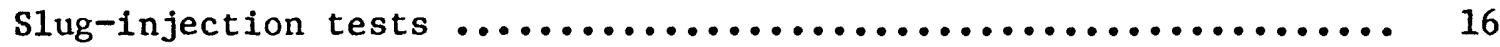

Slug-displacement tests $\ldots \ldots \ldots \ldots \ldots \ldots \ldots \ldots \ldots \ldots \ldots \ldots \ldots \ldots \ldots \ldots \ldots \ldots \ldots$

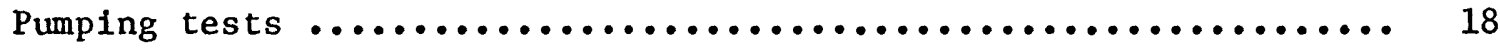

Packer tests $\ldots \ldots \ldots \ldots \ldots \ldots \ldots \ldots \ldots \ldots \ldots \ldots \ldots \ldots \ldots \ldots \ldots \ldots \ldots \ldots \ldots \ldots \ldots \ldots \ldots \ldots$

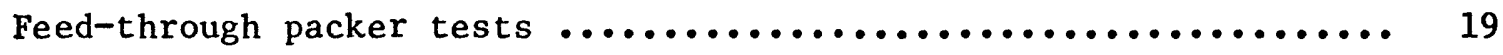

Shut-in tests $\ldots \ldots \ldots \ldots \ldots \ldots \ldots \ldots \ldots \ldots \ldots \ldots \ldots \ldots \ldots \ldots \ldots \ldots \ldots \ldots . \ldots 20$

Slug/flow tests $\ldots \ldots \ldots \ldots \ldots \ldots \ldots \ldots \ldots \ldots \ldots \ldots \ldots \ldots \ldots \ldots . \ldots \ldots$

Standard production packer tests $\ldots \ldots \ldots \ldots \ldots \ldots \ldots \ldots \ldots \ldots \ldots \ldots \ldots \ldots$

Shut-in tests $\ldots \ldots \ldots \ldots \ldots \ldots \ldots \ldots \ldots \ldots \ldots \ldots \ldots \ldots \ldots \ldots \ldots \ldots \ldots . \ldots . \ldots . \ldots \ldots$

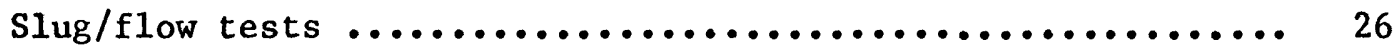

Pressure-pulse tests $\ldots \ldots \ldots \ldots \ldots \ldots \ldots \ldots \ldots \ldots \ldots \ldots \ldots \ldots \ldots \ldots . \ldots \ldots$ 
Summary $\ldots \ldots \ldots \ldots \ldots \ldots \ldots \ldots \ldots \ldots \ldots \ldots \ldots \ldots \ldots \ldots \ldots \ldots \ldots \ldots \ldots \ldots \ldots \ldots \ldots . \ldots \ldots$

Selected references $\ldots \ldots \ldots \ldots \ldots \ldots \ldots \ldots \ldots \ldots \ldots \ldots \ldots \ldots \ldots \ldots \ldots \ldots \ldots \ldots \ldots \ldots \ldots . . \ldots 29$

\section{ILLUSTRATIONS}

Figure 1. Diagram showing well equipped with a single inflatable packer .....................................

2. Diagram showing well equipped with two inflatable packers .. 3

3. Diagram showing Lynes Production-Injection Packer equipped

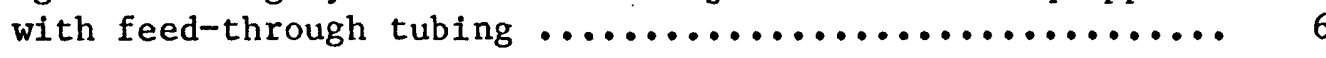

4. Diagram showing Be11 and Howell CEC 1000 pressure transducer ................................... 6

5. Diagram showing Gearhart Owen transducer housing with four-conductor logging-head connector ............... 8

6. Diagram showing pressure transducer and electrical connector protected for submergence in water .......... 8

7. Diagram showing Gearhart Owen four-to-one changeover and single-conductor logging-head connector ........... 11

8. Diagram showing pressure-transmitter current-loop circuit .. 11

9. Diagram showing generalized sequence of formation testing .. 14

10. Diagram showing slug-injection equipment $\ldots \ldots \ldots \ldots \ldots \ldots \ldots$

11. Diagram showing packer tubing circulation assemblies ...... 21

12. Diagram showing seating-nipple/standing-valve assembly .... 21

13. Graphs showing effects of shut-in on recovery of pressure

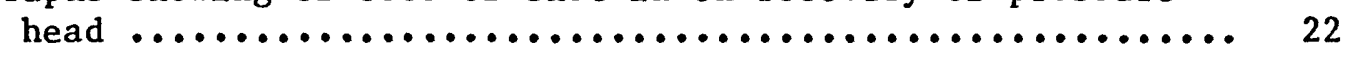

14. Diagram showing standing valve disassembled for modification ................................. 25

15. Diagram showing transducer/standing-valve assembly ....... 25

16. Diagram showing pressure-pulse test equipment $\ldots \ldots \ldots \ldots \ldots \ldots$ 


\section{CONVERSION FACTORS}

In this report figures for measurements are given in inch-pound units only. The following table contains factors for converting to metric units.

Multiply inch-pound units

inch

foot

foot squared per day

gallon

gallon per minute

pound per square inch
By

25.40

0.3048

0.0929

3.785

0.06309

0.07031
To obtain metric units

millimeter

meter

meter squared per day

liter

liter per second

kilogram per square centimeter

National Geodetic Vertical Datum of 1929 (NGVD of 1929): A geodetic datum derived from a general adjustment of the first-order level nets of both the United States and Canada, formerly called "Mean Sea Level." NGVD of 1929 is referred to as sea level in this report.

The use of brand names in this report is for identification purposes only and does not constitute endorsement by the U.S. Geological Survey. 


\author{
INSTRUMENTATION USED FOR HYDRAULIC TESTING OF POTENTIAL \\ WATER-BEARING FORMATIONS AT THE WASTE ISOLATION PILOT PLANT SITE
}

\title{
IN SOUTHEASTERN NEW MEXICO
}

\author{
By J. A. Basler
}

\begin{abstract}
Requirements for testing hydrologic test wells at the proposed Waste Isolation Pilot Plant near Carlsbad, New Mexico, necessitated the use of inflatable formation packers and pressure transducers. Observations during drilling and initial development indicated small formation yields which would require considerable test times by conventional open-casing methods. A pressure-monitoring system was assembled for performance evaluation utilizing commercially available components. Formation pressures were monitored with a downhole strain-gage transducer. An inflatable packer equipped with a $\frac{1}{4}$-inch-diameter steel tube extending through the inflation element permitted sensing formation pressures in isolated test zones. Surface components of the monitoring system provided AC transducer excitation, signal conditioning for recording directly in engineering units, and both analog and digital recording. Continuous surface monitoring of formation pressures provided a means of determining test status and projecting completion times during any phase of testing. Maximum portability was afforded by battery operation with all surface components mounted in a small self-contained trailer.

The transducer system was successfully used for monitoring recovery from balling, slug-injection tests, displacement tests, pressure-pulse tests, and pumping tests. Modification of the transducer assembly for use with the feed-through packer enabled monitoring of shut-in tests, slug tests, and pressure-pulse tests. The monitoring system permitted formation testing to determine transmissivities ranging from $1 \times 10^{-6}$ foot squared per day to 100 feet squared per day.
\end{abstract}

\section{INTRODUCTION}

The first hydrologic test wells at the proposed Waste Isolation Pilot Plant (WIPP) site near Carlsbad were drilled during 1976. The test holes were drilled to determine pressure heads, magnitude and direction of flow, and water chemistry of three water-bearing zones overlying the proposed storage horizon. 
The six test wells drilled in 1976 penetrated all three zones. Two of the test wells were completed with all three zones open to the test well, and four were completed with only the two deepest zones open to the test well. Test wells that were completed open, to only two zones were equipped with a single inflatable packer to isolate the zones and provide a method of measuring water levels in each zone prior to testing (fig. 1). Water levels were measured in the deepest zone through the tubing string used to place the packer, and water levels in the shallowest $z$ one were measured in the well annulus between the casing and packer tubing. Test wells open to the third zone were first equipped with a packer to isolate that zone. After the first packer was placed, the tubing string was removed and another packer was installed to isolate the other two zones (fig. 2). Water-level measurements were then accessible for the two shallowest zones, and the deepest zone was isolated for future testing.

Test wells drilled after 1976 were completed in groups of three in which each well was open to a single zone. Inflatable packers were installed in the test wells when periodic water-level measurements indicated a slow rate of recovery to static conditions after completion. The packer tubing string reduced the well diameter and therefore the volume of formation water necessary for recovery to static.

Thirty wells were drilled for testing. The water-bearing zones detected during drilling and geophysical logging generally exhibited small yields. Open-casing test methods were considered uneconomical in many instances because of the time necessary to complete testing. Utilization of packers to obtain pressure-head data and decrease the time necessary for stabilization of the zones prior to testing required development of a pressure-monitoring system. The effort was then directed at development of a remote monitoring system to minimize manpower requirements in testing by open-casing and packer methods.

\section{Acknowledgments}

The instrumentation was developed for use during a project funded by the Department of Energy in cooperation with the Sandia National Laboratories. Fleld operations support was directed by Robert Statler of Sandia National Laboratories, and scheduling and direction of support operations were the effort of W. E. Cunningham, D. L. Bradley, Wayne Laney, and Matthew Wilson of Fenix and Scisson, Inc.

The author wishes to thank personnel of the Water Resources Division for their efforts. Jerry Mercer, project chief, and Jim Hudson helped with the operation and field evaluation of the equipment. Much of the success of the equipment development was due to the effort of $R$. $K$. DeWees who provided assistance in equipment procurement, operation and evaluation. Kevin Dennehy, Paul Davis, and Jane Wells helped with data analysis and collection. 

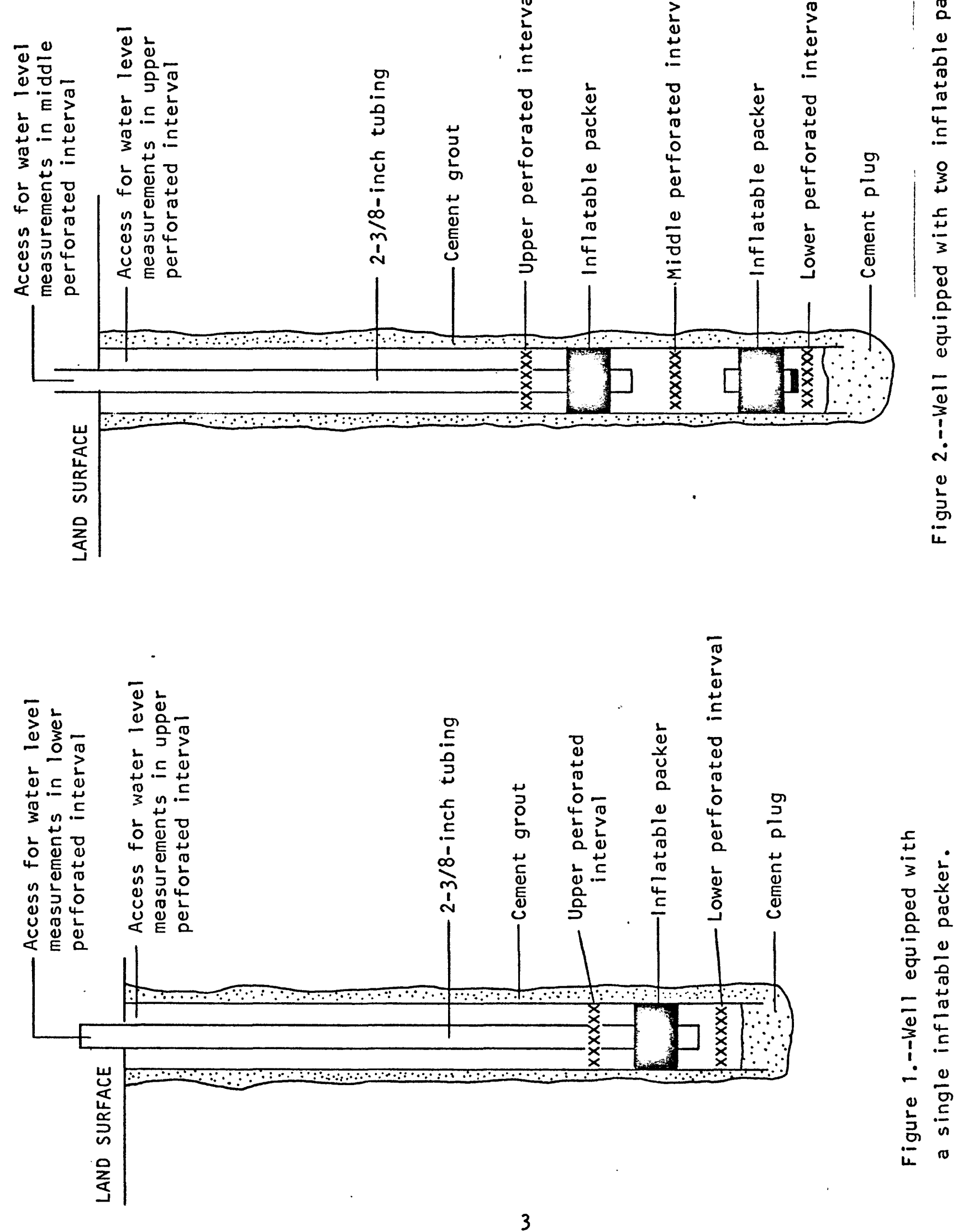


\section{EQUIPMENT REQUIREMENTS}

Equipment requirements were considered and resolved for both the downhole and surface components of the monitoring system. Emphasis was placed on utilization of commercially available components although shop-fabricated items were sometimes necessary to expedite component evaluation and use under test conditions. Portable equipment enclosures and battery operation were necessary to minimize support requirements.

\section{Downhole components}

The downhole components of the monitoring system include: (1) A packer, used to isolate the zone to be tested, equipped with a mechanism to obtain pressures in the isolated zone; (2) a pressure sensor and housing to enable monitoring pressures in the isolated zone during packer tests or measuring water-level fluctuations during open-casing tests; and (3) a cable to transmit the signal from the pressure sensor to the monitoring equipment at land surface.

\section{Packer}

The use of packers in aquifer testing required sensing formation pressures below the packer element. Shuter and Pemberton (1978) discussed a packer-transducer assembly for well testing. Because test wells drilled at the WIPP site after 1976 were constructed to allow formation testing with a single packer and pressure sensor, a shop-fabricated or modified multiple-set multiple-packer assembly was not deemed practical for the WIPP investigations. However, the concepts used in the multiple-packer system led to a solution utilizing a commercially available single-set packer.

An inflatable packer equipped with a $\frac{1}{4}$-inch diameter steel tube extending through the inflation element (fig. 3) is manufactured by Lynes, Inc. The feed-through element is a factory modification of the packers used during pretest monitoring and was designed for a Lynes pressure sensor mounted below the inflation element with the signal cable extended to the surface through the $\frac{1}{4}$-inch diameter steel tubing. The packers (with or without feed-through tubing) are available in several sizes to accomodate a wide range of well-casing diameters. Data resolution, time durations anticipated in testing, and flexibility needed in testing procedures precluded use of the Lynes sensor system available at the time. 
Surface monitoring of downhole formation pressure required the use of a pressure transducer. A pressure transducer provides an output in response to pressure and generally the output is in some form of an electrical signal that can be transmitted on an electrical conductor to a monitoring device.

Transducer selection was primarily governed by size restrictions, long-term stability, and resistance to a corrosive environment. other factors considered were cost, availability, and flexibility in signal conditioning. Size restrictions and economics limited transducer design to piezoelectric, strain gage, and semiconductor whereas long-term stability, signal conditioning, and availability further reduced the design options to the selection of the strain gage type.

The Be11 and Howell CEC 1000 (fig. 4) met or exceeded the transducer requirements, particularly with regard to long-term stability. An added advantage of the gage was its double case insulation, which eliminated the effects of external stresses.

The anticipated range of formation pressures during testing required that the transducers be accurate over a wide range of pressures. Matching the pressure range of a transducer with anticipated test pressures optimized accuracy of the monitoring system. Full scale pressures of 50, 100, 250, $500,1,000$, and 2,000 pounds per square inch satisfied the pressure ranges anticipated for testing at the WIPP site.

\section{Signal cable}

The pressure transducer required two conductors for bridge excitation and an additional two conductors for the output. Two types of four-conductor cable were used. Initially, a steel-armored logging cable mounted on a handoperated reel was used exclusively; however, economics and corrosion in the brine environment led to the use of a light-weight, vinyl-jacketed cable when possible. Belden 8723 instrumentation cable was utilized for shallow packer settings (less than 750 feet) when little or no fluid was anticipated in the annulus above the transducer. Depth and time of submergence of the lightweight cable had to be considered to minimize formation water seeping through the vinyl jacket. 

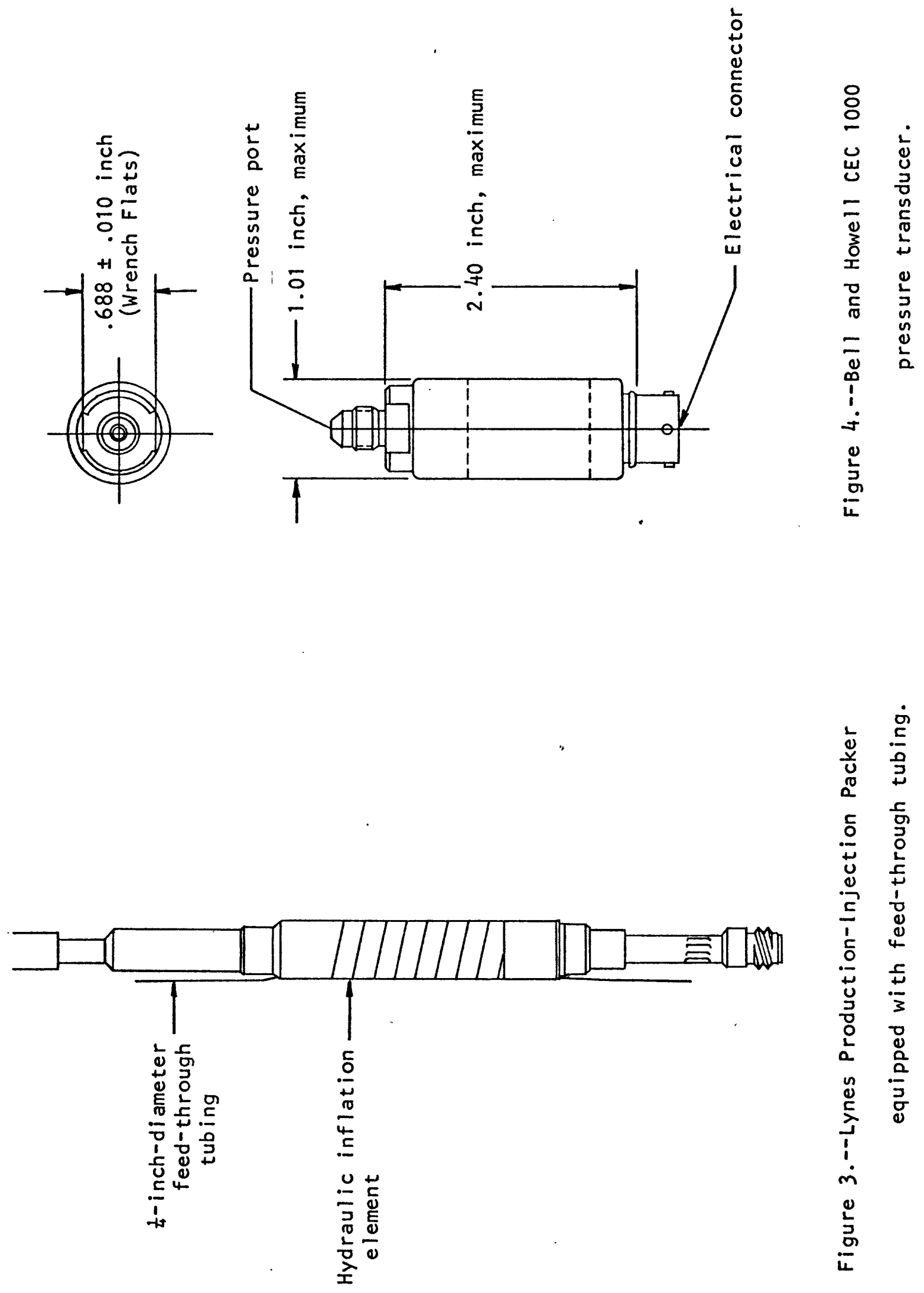


\section{Transducer housing}

Placement of the pressure transducer in the formation water during testing required isolating the electrical conductors from the water and protecting the transducer from physical abuse during installation. A transducer housing (fig. 5) was fabricated by Gearhart Owen Industries and supplied with a four-conductor logging-head connector. After the head connector was attached to the logging cable, the transducer pressure range could be changed for testing by replacing the housing with one containing a transducer with the appropriate pressure range.

For open-casing tests and shallow packer installations the cable and transducer housing requirements were less demanding. The light-weight, vinyl-jacketed cable generally was used with minimal environmental protection. The transducer electrical connector was encapsulated using AMP 603105 thick-wall shrink tubing (fig. 6). Because the transducer is double-cased against external stresses, no additional environmental protection was required.

\section{Surface components}

The surface components of the monitoring system included: (1) An amplifier to provide transducer excitation and signal conditioning; (2) recorders; (3) barometers; (4) calibration equipment; (5) equipment enclosures; and (6) geophysical logging equipment modified for depth-to-water measurements.

\section{Amplifier}

The sensing element of the CEC 1000 transducer consists of a four-active-arm bridge. Each arm is a strain-gage element that changes resistance when stressed. The transducer output is obtained by applying voltage to the bridge and measuring the voltage difference produced by $a$ change in resistance due to stress. Since the transducer is a resistive device, excitation can be from an alternating current ( $A C$ ) or direct current (DC) source. A Validyne CD19 carrier demodulator amplifier provided AC excitation and a variable high-level output compatible to most recording devices. Noise problems generated by long cable lengths and operation of communication equipment were minimized by the AC excitation. The variable high-level output permitted recording of test data in engineering units (pounds per square inch or feet of freshwater head), which greatly facilitated data reduction in the field. Although the mainframe (Validyne MC1-3) for the CD19 was purchased with AC power, it was easily converted to DC battery operation by replacing the power-supply regulation circuit with a DC to DC converter. 

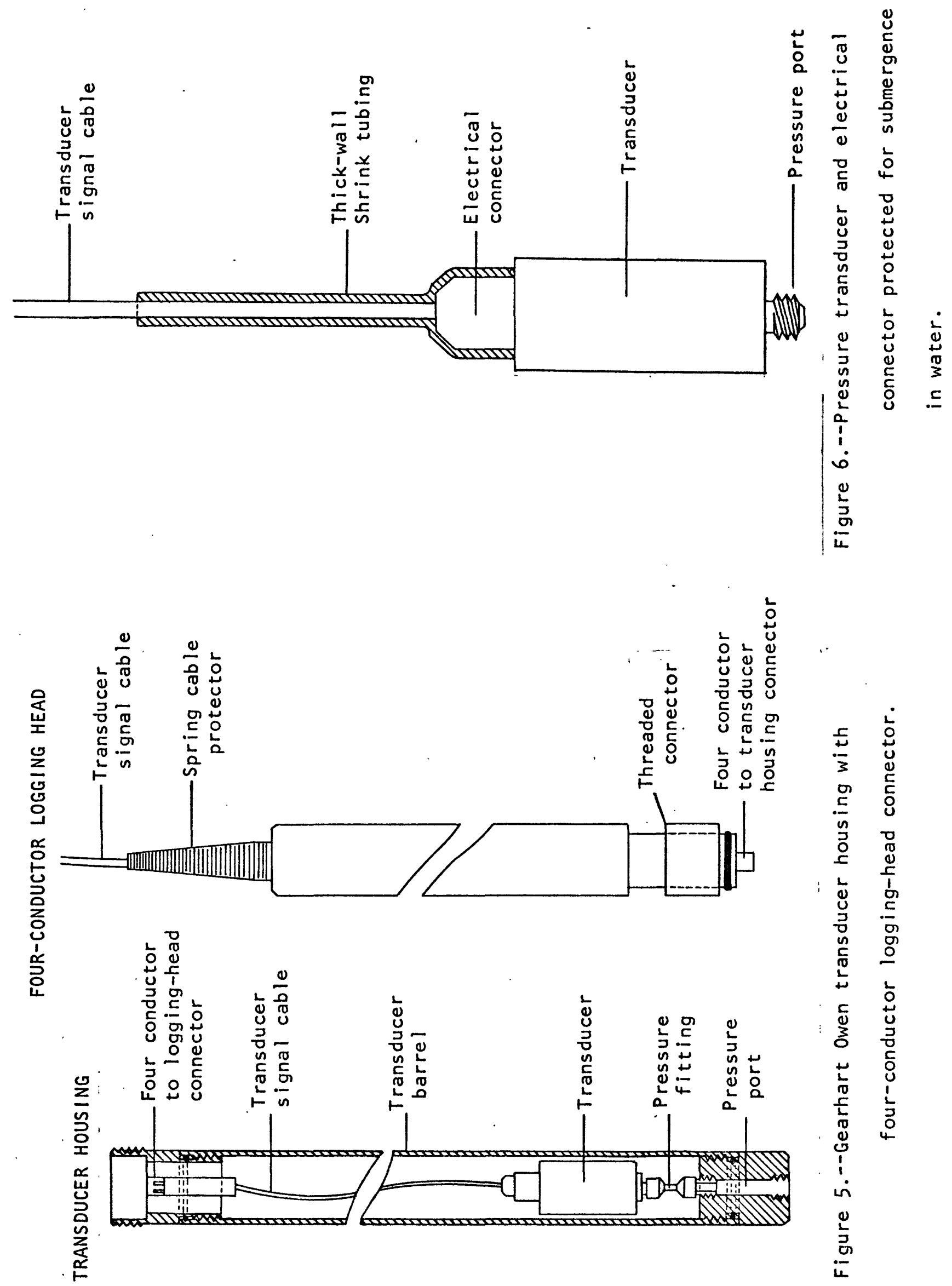


\section{Recorders}

Data recording was accomplished with a Soltec VP-6723S strip-chart recorder and an Esterline Angus PD2064 digital data logger. The strip-chart recorder provided "quick look" analog trends during testing. The data logger with digital printer was the primary recording device and provided time and data resolution not available in an analog device.

\section{Barometer}

The effect of barometric-pressure changes on the confined formation and the pressure transducer during testing necessitated barometric monitoring. A Validyne DB-199 was used to monitor and record barometric pressure, except on very short duration tests. Battery operation of the DB-199 was achieved through use of a DC to $A C$ inverter. In addition to the digital barometer, a Weather Measure Corporation spring-clock-driven, drum-chart, microbarograph was maintained at a central facility. The microbarograph was corrected to sea level and used as a reference when changing location of the digital barometer from one test-well site to another.

\section{Calibration equipment}

Laboratory-component calibrations were necessary in the selection of system components, but stability, measurement resolution, and reliability were determined by an on-site system calibration. A Datel DVC-8500 voltage calibrator was used to verify calibration on recorders and digital meters. Pressure calibration was achieved using a Chandler 23-1 dead-weight tester. Prior to and after each transducer installation, the dead-weight tester was used to verify system calibration.

\section{Equipment enclosures}

Several methods of housing the monitoring equipment were used during testing. The most successful method was to permanently mount the recorders and signal-conditioning equipment in a small self-contained camper-style trailer. In addition to providing adequate environmental protection for the equipment, there was ample space to conduct office duties necessary for completion of the on-site work. Because all associated equipment was contained in a single enclosure, a high degree of portability was obtained. 


\section{Geophysical logging equipment.}

The measurement of water levels deeper than 500 feet and measurements in wet casings presented many problems in equipment maintenance. The usual method involving an electric probe was limited to measurement depths of less than 1,500 feet and the brine environment generally damaged the equipment (probe, contacts, and meter) in a matter of weeks. The DC excitation was changed to AC in an attempt to extend the probe life, and a mechanical footage counter was used to increase the measurement accuracy. The development of a pressure-sensing system provided a more reliable and accurate method of measuring deep water levels using existing geophysical logging equipment.

The pressure transducer and recorders were directly compatible with the four-conductor logging unit available for the project. The transducer housing was supplied with a connector identical to the existing logging probes. The four conductors were traced through the logging cable to determine the proper excitation and signal connections on the logger console. The logger recorder and signal-conditioning modules were then bypassed at the signal patch panel and replaced with the carrier-demodulator amplifier and digital recorder. Normal logging functions were restored by replacing four jumpers on the signal patch panel. Utilization of the four-conductor logger for water-level measurements were limited because of the commitments for geophysical logging.

Increased requirements for the use of a powered winch for deep waterlevel measurements and monitoring resulted in the modification of a singleconductor logging winch to be used exclusively for this purpose. A four-toone changeover (fig. 7) supplied by Gearhart Owen Industries allowed use of the existing transducer housings with the single-conductor logging head. The single-conductor cable, however, necessitated replacement of the pressure transducer with a pressure transmitter. The pressure transmitter functions the same as a pressure transducer but contains circuitry to allow its use in a two-wire current-loop system. Excitation is from a DC voltage source, and the signal is obtained as a voltage drop across a load resistor in the current loop. The Bourns model 5020 transmitter is size and performance compatible to the system. Because the single-conductor cable shield is grounded to the winch cable drive and vehicle electrical system, DC to DC converters were used for excitation and signal-suppression isolation to avoid any ground loops. In addition to the converters, cable, and transmitter, the current loop (fig. 8) contained a variable-load resistor to provide an output signal compatible to the meter and recorder measurement ranges. The surface components (converters, load resistor, panel meter, and recorder) were all rack mounted with the winch-drive controls. 

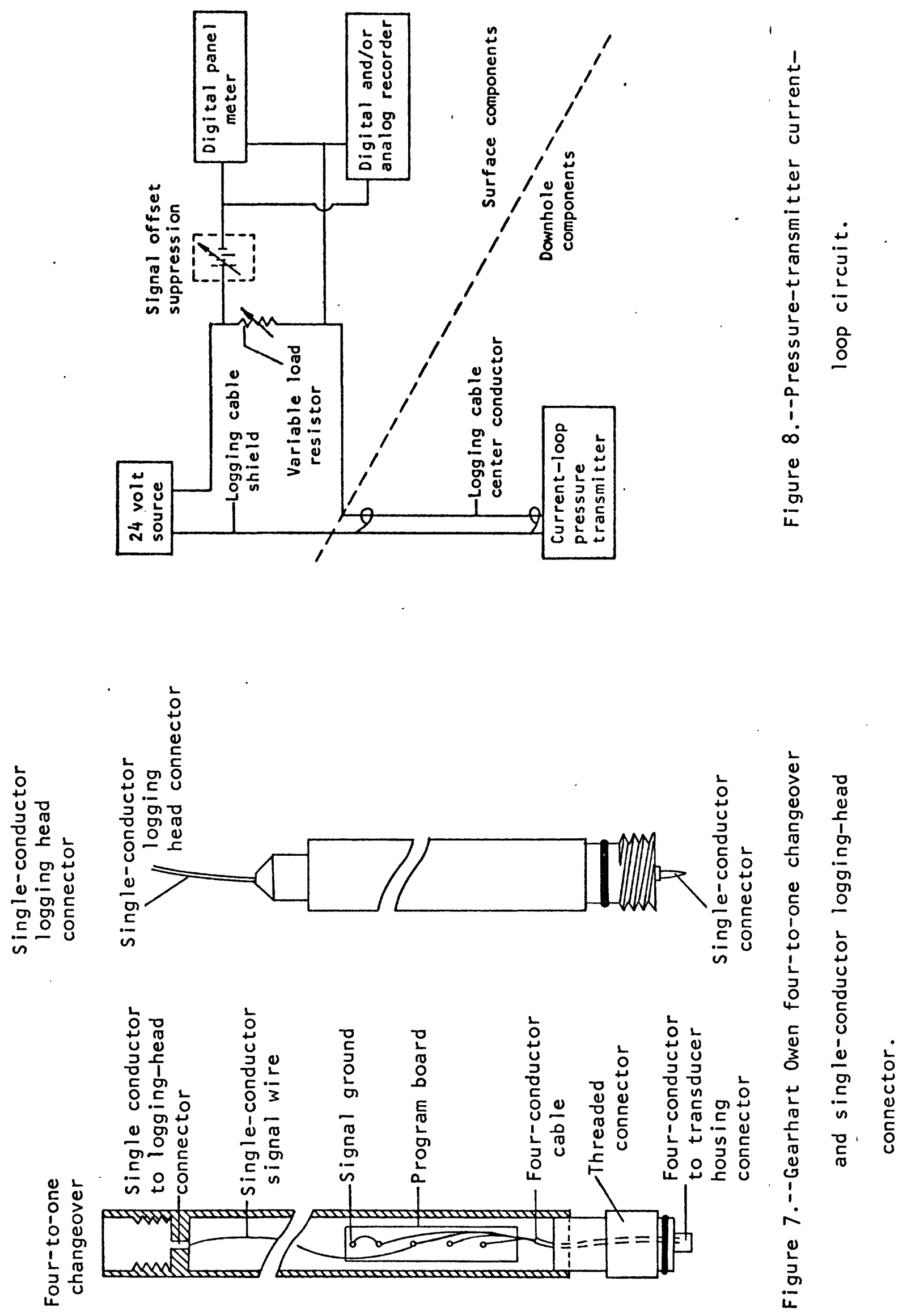


\section{System accuracy}

Each component purchased for, the pressure-monitoring system and calibration of the system was supplied with performance specifications. The system accuracy is dependent upon three calibration factors: 1) The measurement resolution, which can be defined as the accuracy with which pressure is converted to an electrical signal and amplified for recording, 2) the recording resolution, which is the accuracy with which the transducer signal is recorded; and 3) the system calibration, which is dependent upon the accuracy of the calibration device and the procedures used for the system calibration.

The transducers used in the monitoring system have a combined linearity, hysteresis, and non-repeatability of less than \pm 0.25 percent of the full scale output. The thermal error band performance is better than 0.25 percent within any $50^{\circ}$ Fahrenheit (F) band of the compensated temperature range $\left(-65^{\circ} \mathrm{F}\right.$ to $\left.250^{\circ} \mathrm{F}\right)$. The worst-case accuracy of the transducer then can be assumed to be 1 part in 400. The amplifiers used to condition the transducer signal have a zero shift of 0.005 percent $/{ }^{\circ} \mathrm{F}$ and a span shift of 0.01 percent $/{ }^{\circ} \mathrm{F}$. Because the surface components are housed in a controlled environment with an ambient temperature between $65^{\circ} \mathrm{F}$ and $75^{\circ} \mathrm{F}$, the worst-case zero shift would be 1 part in 2000 and the span shift one part in 1000 . The measurement resolution then can be assumed to be better than 1 part in 400 .

The data-logger factory-calibration accuracy is given as \pm 0.01 percent of the reading, \pm 0.015 percent of the span \pm 5 microvolts after 1 hour warmup with the ambient temperature between 20 and 30 degrees Celsius. The \pm 400 millivolt scale was the most commonly used, which would provide a recording resolution of 1 part in 2666 .

The dead-weight tester used for system calibration has an accuracy of 0.1 percent of the indicated pressure. The system-calibration accuracy is then 1 part in 1000 over the calibrated pressure range with the provision that calibration procedures conformed with those specified by the manufacturer.

Measurement resolution, recording resolution, and system calibration are all theoretical values. It can be assumed that the system accuracy could be much improved through on-site observations and checks whenever possible and strict adherence to an on-site quality-assurance program.

The system calibration was performed prior to and immediately following each transducer installation. The calibration was initiated only after ample warmup time for each system component with the transducer stabilized at the surface to the formation temperature. Prior to formation testing, the dead-weight tester was connected to the transducer, and the full-scale pressure applied for span adjustment. A ten-point calibration then was used to establish system linearity and hysteresis. No calibration was considered complete until duplication of the recorded values was obtained on at least two of the ten-point runs. After formation testing had been completed and 
the transducer retrieved from the well, a system calibration was used to check zero drift and span drift during testing. Whenever possible, the calibration checks were performed immediately after removal of the transducer without electrical shutdown or movement of equipment to a new site. The difference between the pre-test calibration and post-test calibration rarely exceeded 1 part in 2500. This resolution exceeded the theoretical system accuracy, but steel-tape measurements (when possible) during testing confirmed this level of accuracy. Recording resolutions of 1 part in 40,000 were sometimes used, but only to detect small changes of 0.01 foot prior to the start of testing.

\section{METHODS OF TESTING}

Well-completion requirements specified in the WIPP drilling contracts included bailing development. Observations made during drilling by air circulation (Mercer and $0 \mathrm{rr}, 1979$, p. 12) and measurements of water-level recovery after bailing development helped to determine the methods to be used for aquifer testing. When the initial data indicated sufficient yields to test by pumping, the yields were verified by open-casing slug tests. The indication of yields insufficient for testing by pumping required low-permeability methods of testing with inflatable packers.

The test wells were completed in a single zone or were completed in multiple zones in such $a$ way as to facilitate single-zone testing. Multiple-zone test wells were usually completed open only to the deepest zone. After testing the deepest zone, a bridge-plug packer was placed above the zone tested and the casing was perforated opposite the next deepest zone. For details on the well-construction methods used, refer to Mercer and orr (1979).

The test procedures used varied considerably depending on data collected during drilling and subsequent testing. A flow chart (fig. 9) has been constructed to illustrate the general sequence followed in testing.

\section{OPEN-CASING TESTS}

Open-casing tests used during the WIPP investigations included recovery from bailing, slug by injection or displacement, and constant-rate pumping. Transducer installation was accomplished by suspending the pressure transducer at a known depth below the water surface on a signal cable secured at the surface. The Belden light-weight. Instrumentation cable was generally used because of portability, ease of installation, and low cost. 


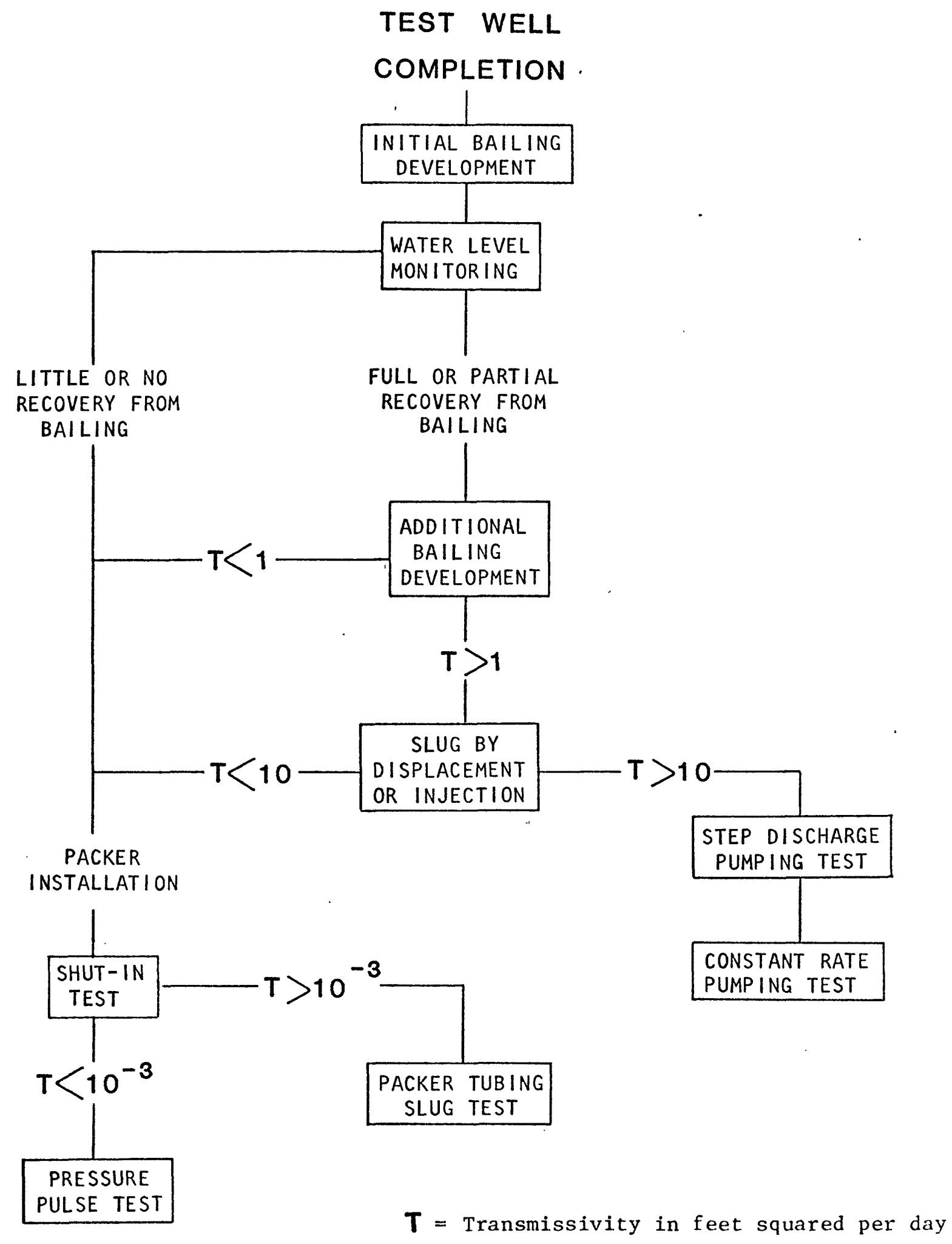

Figure 9.--Generalized sequence of formation testing. 


\section{Recovery from bailing}

The first opportunity to obtain formation-test data occurred with bailing development following completion of the test well. The bailing rate used was about 3 gallons per minute. The volume and rate of water removed during bailing was determined by recording the time of each trip made with the bailer of known volume and the accumulated volume in a calibrated storage tank. The bailing effort was governed by formation yield and stabilization of the formation-water conductance, $\mathrm{pH}$, and temperature. Upon completion of bailing, a transducer was lowered into the well to monitor the rate of recovery.

A 100-pound-per-square-inch pressure transducer was used for monitoring bailing recovery. The transducer signal was amplified to provide a recorder output range of 0 to 2 volts for a pressure range of 0 to 86.6 pounds per square inch ( 0 to 200 feet measured as freshwater head). The amplified signal was recorded on the 4.5-digit data logger, \pm 4 volt range, providing a data-recording resolution of \pm 0.01 foot of freshwater head. Data generally was recorded on 30-second intervals during the first 10 minutes after the transducer placement and 1-to-5-minute intervals after the initial 10 minutes.

The time required for placement of the transducer generally was 1 to 2 minutes. The transducer signal was monitored and recorded until a "quick look" determination could be made on the transmissivity. When the transmissivity was greater than 10 feet squared per day, recovery from balling was at or near static before a transducer could be installed for monitoring. The most reasonable results from analysis of the WIPP bailing recovery data occurred when the transmissivity was in the range of 0.1 to 10 feet squared per day. Data analysis was accomplished using the Theis (1935) recovery method. When the transmissivity was less than 0.1 foot squared per day, the test well generally was bailed dry during development and a determination of the transmissivity was obtained using the slug-test method of analysis described by Cooper, Bredehoeft, and Papadopulos (1967). In treating the data as a slug test, it was assumed that the time of 1 hour required for bailing the well dry was instantaneous compared to the recovery time, which was several days or occasionally weeks.

Because of the limitations and precautions required in the analysis of bailing-test data, the results only were used to determine the type of additional testing to further define the aquifer properties. Corrections for formation-water density generally were not used in the data analysis. 


\section{Slug-injection tests}

When recovery from balling indicated a formation transmissivity greater than 1 foot squared per day, the yield was confirmed using a slug test by injection or displacement.

The slug test by injection was accomplished by a nearly instantaneous injection of a measured volume of formation water (obtained by bailing) into the we11 casing. A 30-foot length of $23 / 8$-inch-diameter tubing was secured inside the well casing at the surface. A transducer then was lowered into the formation water in the well and monitored until the water level was observed to be stable. A high-volume, rig-mounted circulation pump was used for injection. A valving system ( $\mathrm{fig}$. 10) allowed surface circulation to achieve full pumping capacity before the start of injection. Times were recorded for the beginning and end of injection. It took about 40 seconds to inject 200 gallons. A 250-pound-per-square-inch pressure transducer, which provided a recording resolution of \pm 0.01 foot over a range of 0 to 400 feet of freshwater head, generally was used. The transducer signal was recorded at 2-second intervals during the initial 2 minutes of the test. Data-recording intervals, after the initial 2 minutes, were increased for compatibility with the logarithmic time scale used in data analysis. The data were analyzed using the method described by Cooper, Bredehoeft, and Papadopulos (1967). Results obtained were considered reliable when the time monitored for recovery to near static was at least ten times greater than the injection time.

\section{Slug-displacement tests}

A nearly instantaneous formation head change was obtained using a displacement barrel suspended on a cable from the surface. The slug-displacement test was initiated by either lowering the barrel into the water or withdrawing the barrel from the water in the well. The initial displacement tests were conducted using a work-over rig to support the barre1. The barrel was fabricated using a 10-foot length of 4-inch-casing sealed at both ends. Later, a desire for flexibility in testing procedures led to the use of the logging winch and a 3-inch-diameter water-sampling tool as the displacement barrel.

Prior to lowering the displacement barrel into the test well, a transducer was installed below the formation water level and the signal cable secured at the surface. The pressure transducer used for monitoring the displacement tests was a 50-pound-per-square-inch unft. The transducer signal was amplifled to accommodate a recording resolution of 0.001 foot over a range of 0 to 40 feet of freshwater head. The transducer signal was monitored and recorded to confirm a stable water level before testing. The displacement barrel then was lowered into the test well and suspended above the water 


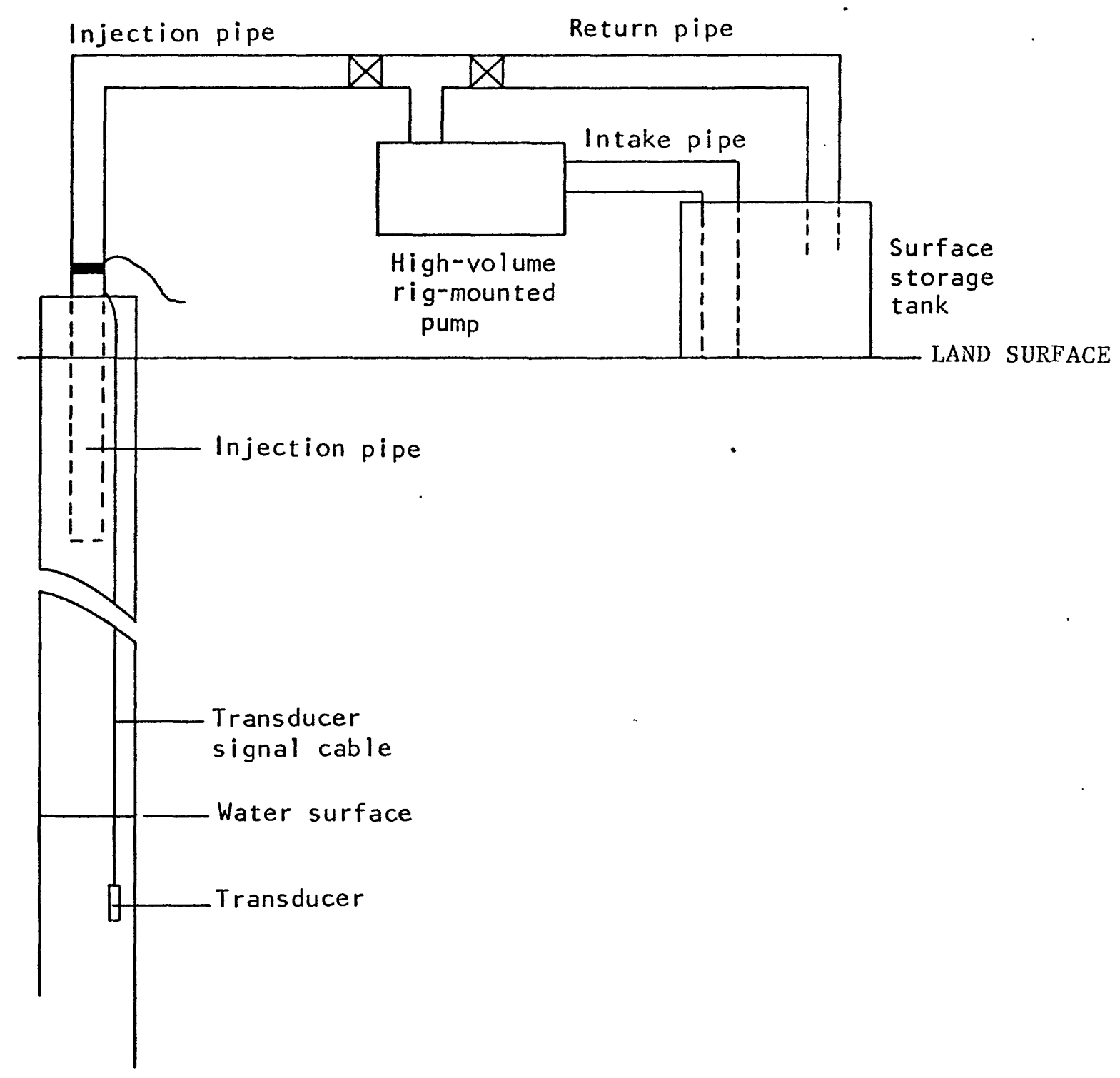

Figure 10.--Slug-injection equipment. 
level. When the water level was observed to be stable, the test was inftiated by lowering the barrel into the water, causing a nearly instantaneous rise in the water level. The 4-inch-dlameter barrel displaced about 3 feet of water in 8-inch-diameter casing and the 3-inch-diameter barrel displaced about 1 foot of water in 6-inch-diameter casing. Data recording and analysis were accomplished in the same manner as the slug-injection. After the recovery of the displacement test and when the water level again was stable, the barrel was ralsed above the water level, causing a nearly instantaneous decline in the water level. The rate of recovery again was monitored and analyzed by the same method.

The displacement-type slug-test was generally preferred over the slug by injection because less equipment was required for testing, there was no requirement for injection water, and the displacement was more instantaneous. Analysis of the slug test data was limited to transmissivities smaller than 100 feet squared per day because of the recording methods used. Magnetictape and oscillographic recorders are being investigated to expand the useful range of slug testing.

\section{Pumping tests}

Final formation testing by constant-rate pumping was performed when the transmissivity determined by prior testing was greater than 10 feet squared per day. After installation of the test pump, a transducer was lowered into the well annulus below the projected pumping water level and the signal cable secured at the surface. A series of step-discharge tests was used to confirm development of the well and to help determine a discharge rate for the constant-rate pumping tests. After completion of the step-discharge tests, the formation water level was monitored to recovery and for an additional period of time necessary to determine any regional effects on the water level. When the pretest monitoring conditions were satisfied, a constant-rate pumping test was started. The test was monitored with a digital meter and recorded by the analog and digital recorders. A 250-pound-per-square-inch pressure transducer was used that provided a recording resolution of 0.01 foot over a range of 0 to 400 feet of freshwater head.

Discharge rates of pumping tests conducted ranged from 10 to 85 gallons per minute. The discharge rates were determined using a Corad totalizing in-line water meter which previously had been calibrated using a stop watch and container. 


\section{PACKER TESTS}

Small yields precluded testing 'most wells by open-casing methods. Techniques designed to limit the volume of formation water required for testing were utilized. These testing methods involved isolating the formation with an inflatable packer to obtain formation head pressures, followed by testing through the tubing used to install the packer. Two types of inflatable packers were used during testing, one equipped with a transducer for monitoring formation pressure (feed-through packer) and the other a standard production-injection packer (PIP) instrumented from the surface following packer installation. The packer tests used during the WIPP investigations included shut-in, slug, flow, and pressure-pulse.

Every attempt was made to insure the integrity of the chemical quality of the formation water. The packers used in testing were hydraulically inflated using formation water as the medium. Foreign water was seldom utilized in testing and was removed at the first opportunity.

\section{Feed-through packer tests}

When utilizing the feed-through packer in formation testing, the transducer was secured to the packer tubing for installation. The feed-through packer tubing was used as a hydraulic connection, transmitting formation pressures from below the packer inflation element. The transducer housing was secured above the packer with the pressure port connected to the feed-through tubing by a short length of polyethylene tubing. The flexible tubing and feed-through tubing were purged by siphoning formation water through the line before securing the tubing to the transducer housing. This process insured a hydraulic connection with the formation water once the packer was in place for testing.

Two methods were used to open the packer tubing to the formation for testing. A shear plug or circulating sleeve was connected to the packer tubing below the inflation element (fig. 11). Once the packer was set, the shear plug was knocked out using a sinker bar lowered by the work-over rig. After the plug was removed, formation water entered the packer tubing through the open end. The circulating sleeve was opened by dropping a steel bar into the water-filled tubing. When the bar struck the sleeve, it was driven down, exposing the circulation ports and allowing formation water to enter the tubing string.

A seating nipple was connected to the packer mandrel above the inflation element, thus becoming a part of the packer-tubing string. The function of the nipple was twofold. If swabbing was anticipated to obtain a formationwater sample, the nipple was an effective means to safeguard against running the swab block through the packer mandrel. Mercer and orr (1979, p. 14) discuss the mechanics associated with swabbing to obtain formation-water 
samples. Also, the seating nipple was part of a mechanism that could be used to seal off the tubing from the formation after circulation had been established. The standing valve was the mating part to the seating nipple. It was lowered into the packer tubing by the work-over rig and sealed off the tubing from the formation when engaged with the seating nipple (fig. 12).

After the packer assembly had been made up with a circulation sleeve or shear plug, transducer, and seating nipple, the assembly was lowered into the test well on a string of 2 3/8-inch-diameter tubing. A teflon-base thread lubricant was used to minimize contamination of the formation water. Each joint of tubing was measured and the length recorded to determine the packer depth when set. The transducer cable was secured to the tubing and protected at each joint by filament tape. When the packer was installed in test wells with casing diameters smaller than 5 inches or at packer depths greater than 750 feet, stee1-collar protectors were used at each tubing joint to protect the cable. When the transducer pressure port entered the formation water, installation was stopped and the packer tubing was raised until the pressure port was above the formation water level. Installation was resumed after the amplifier offset was adjusted for a zero-signal output to the recorders. After the zero-output adjustment, the transducer signal indicated the height of the formation water in feet of freshwater above the pressure port.

Several transducer pressure ranges were used during the packer tests. Whenever possible, a 250- or 500-pound-per-square-inch unit was used to maintain a recording resolution of 0.01 foot. Recording resolutions of the higher pressure range transducers was limited to 0.1 foot.

\section{Shut-in tests}

When the packer was placed at the predetermined test depth, the packer tubing was pressured with a rig-mounted pump for packer inflation. A detailed discussion of the inflation mechanics may be found in Blankennagel (1967). During packer inflation, the recorders were monitored to determine the instant the test zone was shut-in. If the water level in the test well was below static when the packer was inflated, an increase in the rate of recovery was observed (fig. 13). Data recorded during the shut-in was analyzed using the Theis (1935) recovery method.

Occassionally, the formation was capable of yielding so little water that upon inflation of the packer, compression of the formation fluid caused an over-pressure (fig. 13). The recovery from over-pressure was then recorded and analyzed as a pressure-pulse test using the method described by Bredehoeft and Papadopulos (1980).

After the formation pressure had stabilized during the shut-in, the formation static hydraulic head was calculated. The calculation was made using the recorded static hydraulic head, corrected for the formation fluid density, and the depth of the transducer pressure port. 

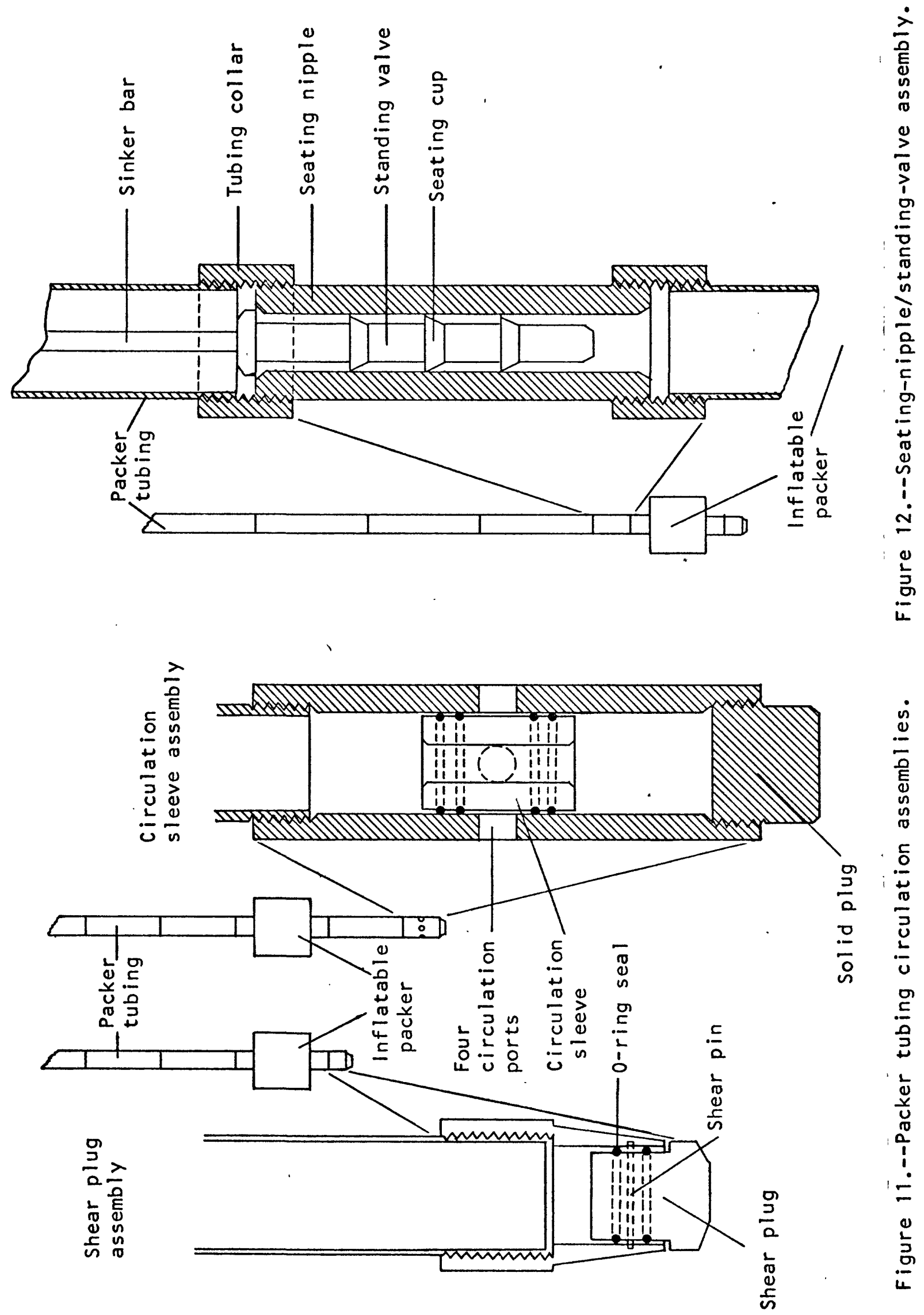


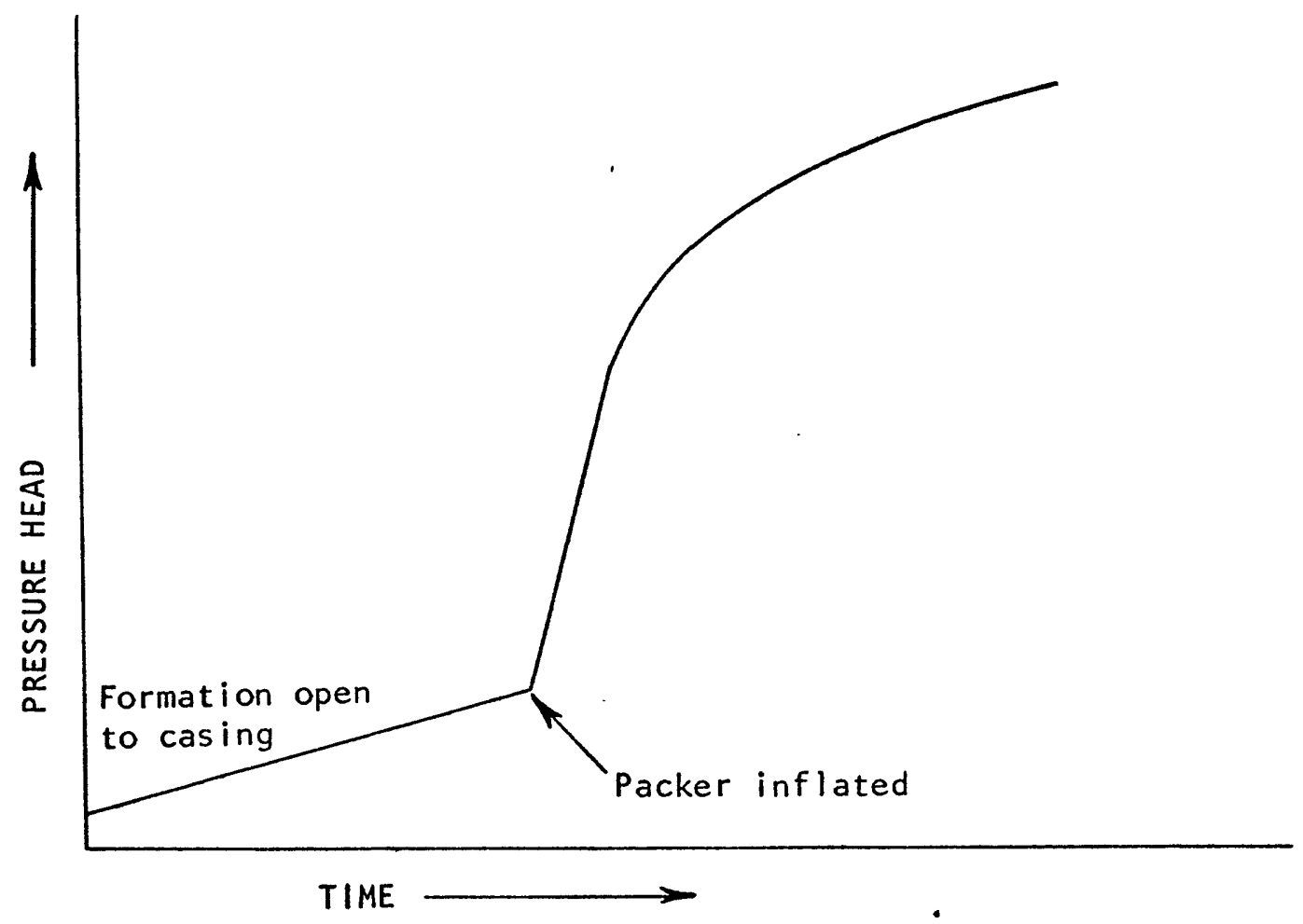

(a) Normal increased recovery rate following packer inflation.



(b) Formation over pressured during packer inflation.

Figure 13.--Effects of shut-in on recovery of pressure head. 


\section{Slug/flow tests}

During the shut-in test, formation water obtained during bailing was used to fill the tubing above the packer. After the formation pressure had stabilized, a slug test was initiated using the water in the packer tubing. Prior to infiating the test, the data logger was set on a 2-second recording interval. The tubing then was opened to the formation by activating the circulation sleeve or removing the shear plug. Data recording continued, on a sample interval compatible with the data-plot time scale, until sufficient data had been collected for analysis. Data analyis of the slug test was accomplished by the method described in Cooper, Bredehoeft, and Papadopulos (1967).

Testing through the packer tubing decreased the diameter of the water column and thereby the change in volume of water in the column per unit change in head. The 2-inch inside-diameter tubing shortened the duration of a slug test in 4-inch-diameter casing by a factor of four, in 6-inch casing by a factor of nine, and in 8-inch casing by a factor of 16. Packer-tubing slug tests were used in testing zones with transmissivities ranging from $1 \times 10^{-3}$ to 10 feet squared per day. Slug-testing zones with transmissivities smaller than $1 \times 10^{-3}$ foot squared per day required considerable time, although four long-duration slug tests were conducted as a base for comparing methods of testing. The time duration of the four tests averaged 300 days, with an average transmissivity of $1 \times 10^{-5}$ foot squared per day.

After sufficient data had been recorded for analysis during the slug test, additional testing could be accomplished using the standing valve. The standing valve was attached to a swab bar and lowered into the packer tubing by the work-over rig. When the standing valve engaged the seating nipple, the tubing was sealed and the zone shut-in. The tubing was again filled with formation fluid, and the slug test was initiated by raising the standing valve, thereby exposing the zone instantaneously to the fluid head in the tubing. Any number of slug and shut-in tests could be conducted in this manner.

When insufficient formation fluid had been obtained from bailing or the fluid lost from balling, a flow (reverse slug) test was used. Freshwater generally was used to inflate the packer and was removed from the packer tubing with a tubing baller during the shut-in test. The test, when Initiated, allowed formation water to flow into the drill stem. Data collection and analysis were achieved by the same methods as in the slug test. 


\section{Standard production packer tests}

The Lynes production-injection-packer (PIP), without feed-through tubing for transducer monttoring, was installed to permit long-term water-level monitoring of dual-completion wells. The zone below the PIP was monitored by measuring the depth to water inside the packer tubing; the zone above the PIP was monitored by measuring the depth to water in the annulus between the well casing and the packer tubing. The PIP also was used to stabilize very low yield zones prior to testing by leaving the circulation sub intact after installation of the packer. Testing of these zones required removal of the PIP and installation of a test packer and transducer. In many instances it was desirable to test the zone below the packer without removing the PIP. A transducer/standing valve assembly was fabricated that permitted formation testing through the PIP when the PIP tubing string included a seating nipple.

A standing valve was disassembled and the end plug discarded (fig. 14). A transducer housing was modified by machining threads on the end to match the threads on the standing valve. Threads also were machined on the cable end of the transducer housing to match the threads of the ball-valve sub of the standing valve. The assembly was made up with the seating cups on the lower end of the transducer housing and the ball-valve sub between the transducer housing and the sinker bar (fig. 15). The sinker bar was attached to the cable of a work-over rig to raise and lower the assembly in the packer tubing. The transducer signal cable was fed through an existing hole in the ball-valve sub and along a slot milled groove to the sinker bar. The sinker bar was attached to a $\frac{1}{2}$-inch-diameter cable supported by a work-over rig. During installation the transducer cable was secured to the sinker bar and rig cable at 50-foot intervals. Communication with the water in the packer tubing was accomplished by circulation through the open end of the standing valve attached to the lower end of the transducer housing.

\section{Shut-in tests}

The transducer/standing-valve assembly was used to monitor shut-in pressures when the PIP-tubing string included a seating nipple above the packer. If the plug in the circulation sub on the end of the packer was intact, the plug first had to be removed with a knockout bar. When the transducer/standing valve entered the formation water inside the PIP tubing, the transducer signal level was adjusted to zero. Installation continued until a loss of cable weight indicated the assembly was resting on the seating nipple. The assembly was then raised about 10 feet and dropped, seating it in the nipple. Since the transducer signal was zeroed when entering the formation water, the pressures recorded during the shut-in were in units above the transducer in the assembly. A PIP-tubing tally was necessary to convert the pressures to depths below land surface. 

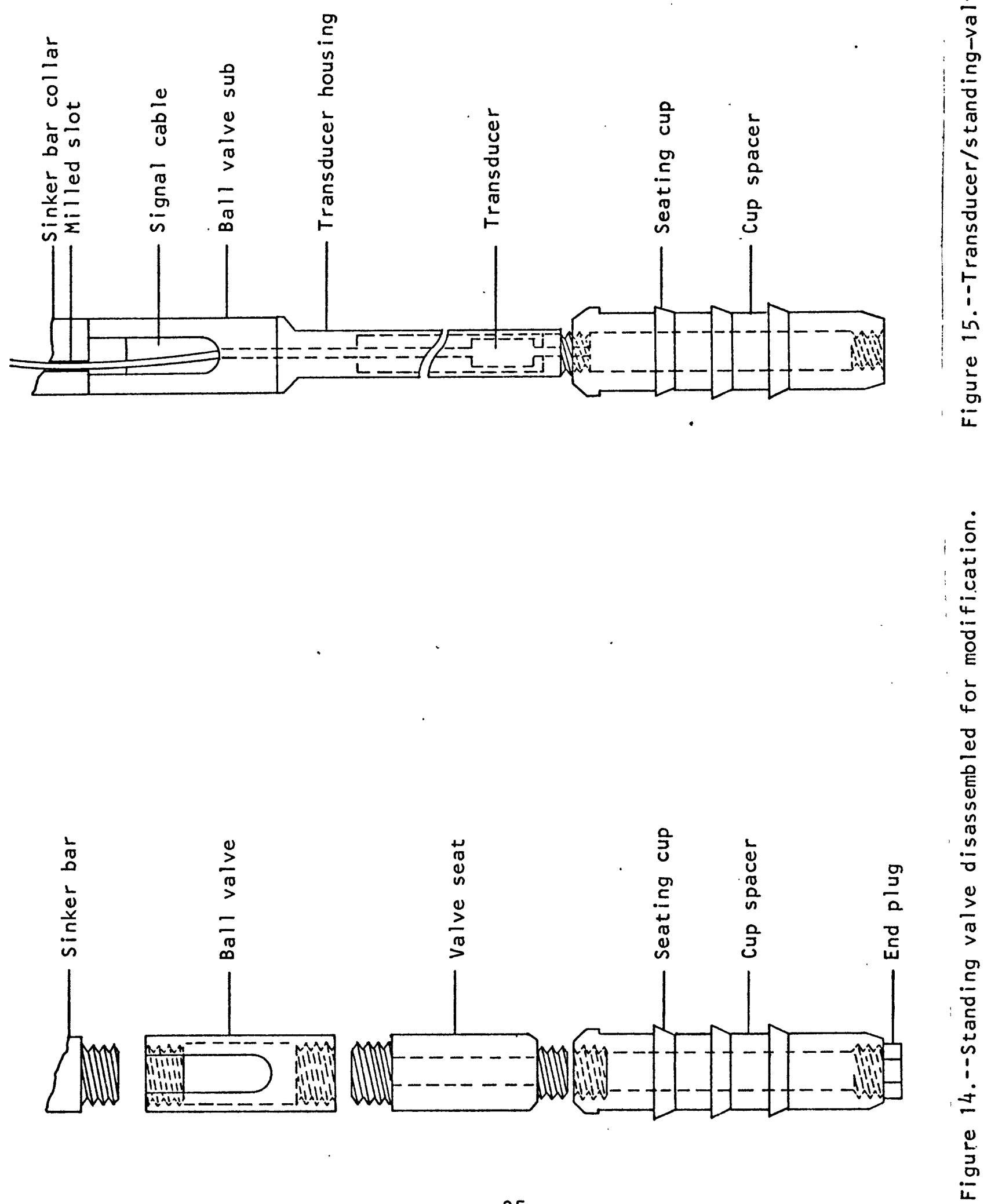


\section{Slug/flow tests}

After the shut-in pressures had stabilized, a slug or flow test generally was run. Formation water for slug testing was obtained by swabbing or was stored from prior testing. If the zone would not yield enough water for a slug test, a flow test generally was used. Either test was initiated in the same manner. The cable supporting the transducer/standing- valve assembly was marked at a convenient reference point at the surface. The assembly was raised in the tubing until a pressure change indicated the seating cups were disengaged from the seating nipple and the formation below the packer open to the tubing string. The reference mark on the cable was used to determine the amount of transducer travel and calculate the transducer depth in the tubing.

The advantages of using the standing valve for testing are: (1) Tests can be conducted on any existing packer installation that includes a seating nipple in the packer-tubing string; (2) the testing does not require leaving the pressure transducer in the test well when it is not convenient to remove the packer after completion of testing; and (3) instrumentation failures can be remedied without removal of the packer assembly. The greatest disadvantage is that a work-over $\mathrm{rig}$ is required to support the valve assembly during testing. The use of softer seating cups is being Investigated; their use might permit utilization of the four-conductor logging winch for the standing-valve transducer applications. The seating cups presently being used require pulling stresses exceeding the safe operating limits of the logging winch and cable.

\section{Pressure-pulse tests}

The pressure-pulse method of testing described by Bredehoeft and Papadopulos (1980) was used in determining transmissivities ranging from $1 \mathrm{x}$ $10^{-6}$ to $1 \times 10^{-3}$ foot squared per day. The testing procedure required filling the drill stem with water, pressuring the water in the drill stem, and monitoring the pressure decay with respect to time.

When available, formation water was used to fill the packer tubing. Because of the small yields associated with this method of testing, water from another source was generally required, but was promptly removed by bailing upon completion of testing. A valve assembly, pressure gage, 50-pound-per-square-inch pressure transducer, and hand-operated piston pump were connected to the drill stem at the surface (fig. 16). With both valves open, water was pumped through the surface plumbing and vented out the bleed valve until the system was observed to be devoid of air. The bleed valve then was closed, and the pressure gage monitored until a pressure of about 20 pounds per square inch was achieved. Although the Baker piston pump used was rated at 1,000 pounds per square inch, test pressures were kept below 


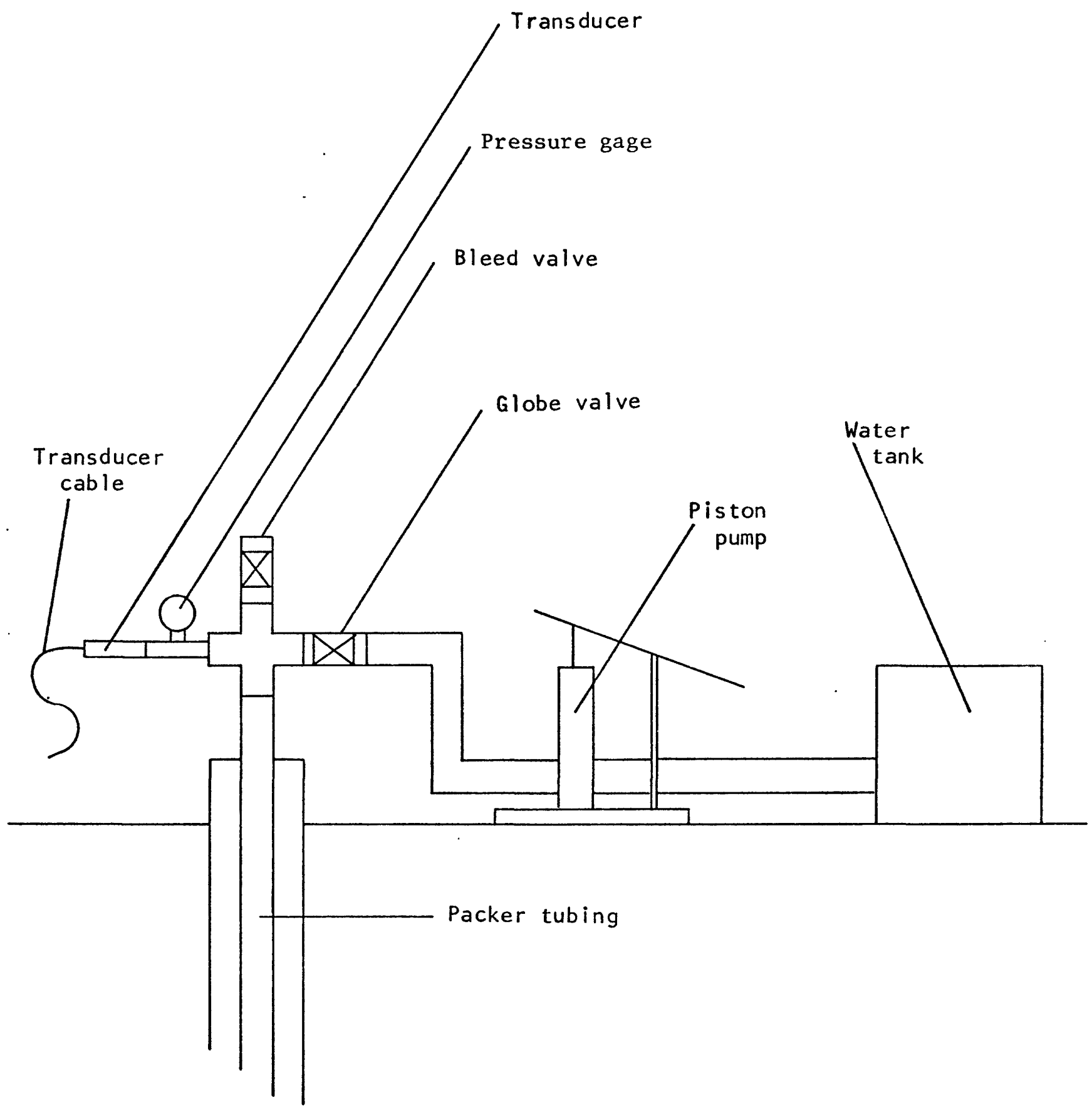

Figure 16.--Pressure-pulse test equipment. 
50 pounds per square inch to minimize plumbing leaks and to avoid physically altering the formation. The digital recorder was set on a 2-second sample interval prior to closing the bleed valve. When the test pressure was achieved, the globe valve was closed to prevent any pressure leaks through the pump. The process of developing a pressure pulse and closing-in the system for monitoring was accomplished in less than 10 seconds. The recording resolution achieved using a 50-pound-per-square-inch transducer allowed detection of 0.01 pound per square inch. Test data from slug tests requiring 260 days of monitoring were duplicated in 3 hours with the pressure-pulse method. Comparison of the results from the data analysis of the two methods were within the same order of magnitude.

\section{SUMMARY}

The pressure-monitoring system was assembled using commercially avallable components. The monitoring equipment was battery operated and housed in trailers and vehicles to minimize support requirements and provide portability. The pressure sensor, a strain-gage transducer, was AC excited and the signal conditioned with a carrier-demodulator amplifier. Both analog and digital data-recording devices were utilized. A strip-chart recorder provided instant data trends, and a digital data logger was used to provide recorded data and time resolution not available with the analog recorder. The transducer was supported by the signal cable during open-casing tests and coupled with an inflatable packer for testing isolated zones. Transmissivities determined during formation testing ranged from $1 \times 10^{-6}$ to $1 \times 10^{2}$ feet squared per day. 


\section{SELECTED REFERENCES}

Blankennage1, R. K., 1967, Hydraulic testing techniques of deep drill holes at Pahute Mesa, Nevada Test Site: U.S. Geological Survey open-file report, $50 \mathrm{p}$.

Bredehoeft, J. D., and Papadopulos, I. S., 1980, A method for determining the hydraulic properties of tight formations: Water Resources Research, v. 16., no. 1 , p. 233-238.

Cooper, H. H., Jr., Bredehoeft, J. D., and Papadopulos, I. S., 1967, Response of a finite-diameter well to an instantaneous charge of water: Water Resources Research, v. 3, no. 1, p. 263-269.

Dennehy, Kevin F., and Davis, Paul A., 1981, Hydrologic testing of tight zones in Southeastern New Mexico; Ground Water Journa1, vol. 19, no. 5, p. 482-489.

Mercer, J. W., and Orr, B. R., 1979, Interim data report on the geohydrology of the proposed Waste Isolation Pilot Plant site, southeast New Mexico: U.S. Geological Survey Water-Resources Investigations 79-98, 179 p.

Shuter, E., and Pemberton, R. R., 1978, Inflatable straddle packers and associated equipment for hydraulic fracturing and hydrologic testing: U.S. Geological Survey Water-Resources Investigations 78-55, $16 \mathrm{p}$.

Theis, C. V., 1935, The relation between the lowering of the piezometric surface and the rate and duration of discharge of a well using ground-water storage: American Geophysical Union Transactions, pt. 2, p. 519-524. 